\title{
ANOPLOPHORA CHINENSIS (FORSTER, 1771) (COLEOPTERA: CERAMBYCIDAE) REPORTED AT NEW LOCATION IN TURKEY
}

\author{
YILDIZ, Y. \\ Bartin University, Faculty of Forestry, Department of Forest Engineering, 74100 Bartin, \\ Turkey,e-mail: yafesyildiz@hotmail.com \\ phone: +90378-223-51-64; fax: +90378-223-50-66 \\ (Received $31^{\text {st }}$ Jan 2017; accepted $3^{\text {rd }}$ Jul 2017)
}

\begin{abstract}
Invasive alien insect species have fast growth and reproduction, high spreading ability, tolerance tovery different enviromental conditions and ability to feed with many plant species. The increase in importing of the plants in the recent years has been causing the prensence of these species in Turkey. One of the these species, Anoplophora chinensis (Forster, 1771) (Coleoptera: Cerambycidae) citrus longhorned beetle was recorded for the first time in Marmara region, Istanbul, Turkey by Hizal et al (2015). This study is a second report for the presence of releated pest in Turkey. The new location (Bartin), in the western Black Sea region, shows that the insect is expanding its distribution area in Turkey.
\end{abstract}

Keywords: Anoplophora chinensis, citrus longhorned beetle, Cerambycidae, new location, Turkey

\section{Introduction}

The genus Anoplophora (Coleoptera: Cerambycidae) consists of 36 species of longhorned beetles indigenous to the temperate and tropical regions of Asia (Lingafelter and Hoebeke, 2002). Among these species, the citrus longhorned beetle, Anoplophora chinensis is a poliphagous woodboring beetle native to Eastern Asia with a host range quite wide causes damage on more than 100 species of trees and shrubs (Peverieri et. al., 2012; EPPO, 2013a). The beetle gets its name from the damage caused to citrus groves in its native China. Unlike many cerambycids that primarily attack dead trees, this beetle attacks apparently healthy trees and sever tissues that carry nutrients, water, and subsequently kill the host tree (Chambers, 2002; Lance, 2002).

The citrus longhorned beetle has been introduced to Europe on several occasions. It was first discovered in Europe in 2000 at Parabiago, Italy and respectively it has been recorded in Netherlands and France (2003) and Switzerland (2006) according to FAO (2009). In Italy more than 18000 plants have been removed for the eradication program and the cost has amounted to about 12 million euros (Jucker and Lupi, 2011). Adults of $A$. chinensis were captured on 12 June 2014 in Sile region of Istanbul province and it was given as a new record to Turkish invasive alien insect species fauna by Hizal et al. (2015).

A. chinensis is a new threat on a wide range of broadleaved trees and shrubs in Turkey. Therefore its distribution areas and the behaviour of the pest in these areas should be investigated.

\section{Materials and Methods}

A total number of 28 adult samples were collected from a private nursery in Bartin region on ornamental plants consisting of Acer palmatum purperea, A. negundo flamingo and A. platanoides by a Japanese umbrella. Specimens were photographed with Samsung Pro-815 digital camera and they were examined under the Olympus 
SZX7 stereomicroscope. The identification process was carried out using specific literature (Lingafelter and Hoebeke, 2002; Gyeltshen and Hodges, 2005; EPPO, 2013a). The samples are stored in the collection of Bartin University, Faculty of Forestry, Department of Forest Entomology and Protection.

\section{Results and Discussion}

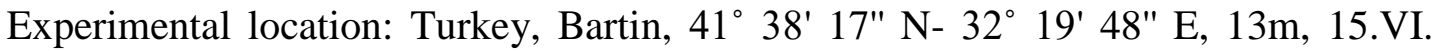
2014 1ठ, 17.VI. 2014, $5 \hat{\jmath}, 10$ q, 19.VI. 2014, 3, 9 ㅇ

\section{Morphology}

The beetle is large, stout, and approximately 21 to $37 \mathrm{~mm}$ long with shiny black elytra marked with 10 to 20 white round spots (Lingafelter and Hoebeke, 2002). Generally males are smaller than females, and have their abdomen tip entirely covered by the elytra, in contrast to the partially exposed abdomen of females. Also, the male elytra are distally narrowed compared to the rounded female elytra. Another difference between males and females are antennal sizes. The male's antennae are approximately twice as long as its body compared to the female's antennae which are only slightly longer than the body. Each segment of the long, 11-segmented antennae is basally marked with white or light blue bands (Gyeltshen and Hodges, 2005). The anteriorly and posteriorly narrowed pronotum has a pair of stout spines extending from its sides and some with two blue and white tufts of hair on pronotum (EPPO, 2013a). The base of the elytra has numerous short tubercules/granulae, a morphological character that may help to differentiate Anoplophora chinensis from the, A. glabripennis (Gyeltshen and Hodges, 2005) (Figure $1 A-D$ ).

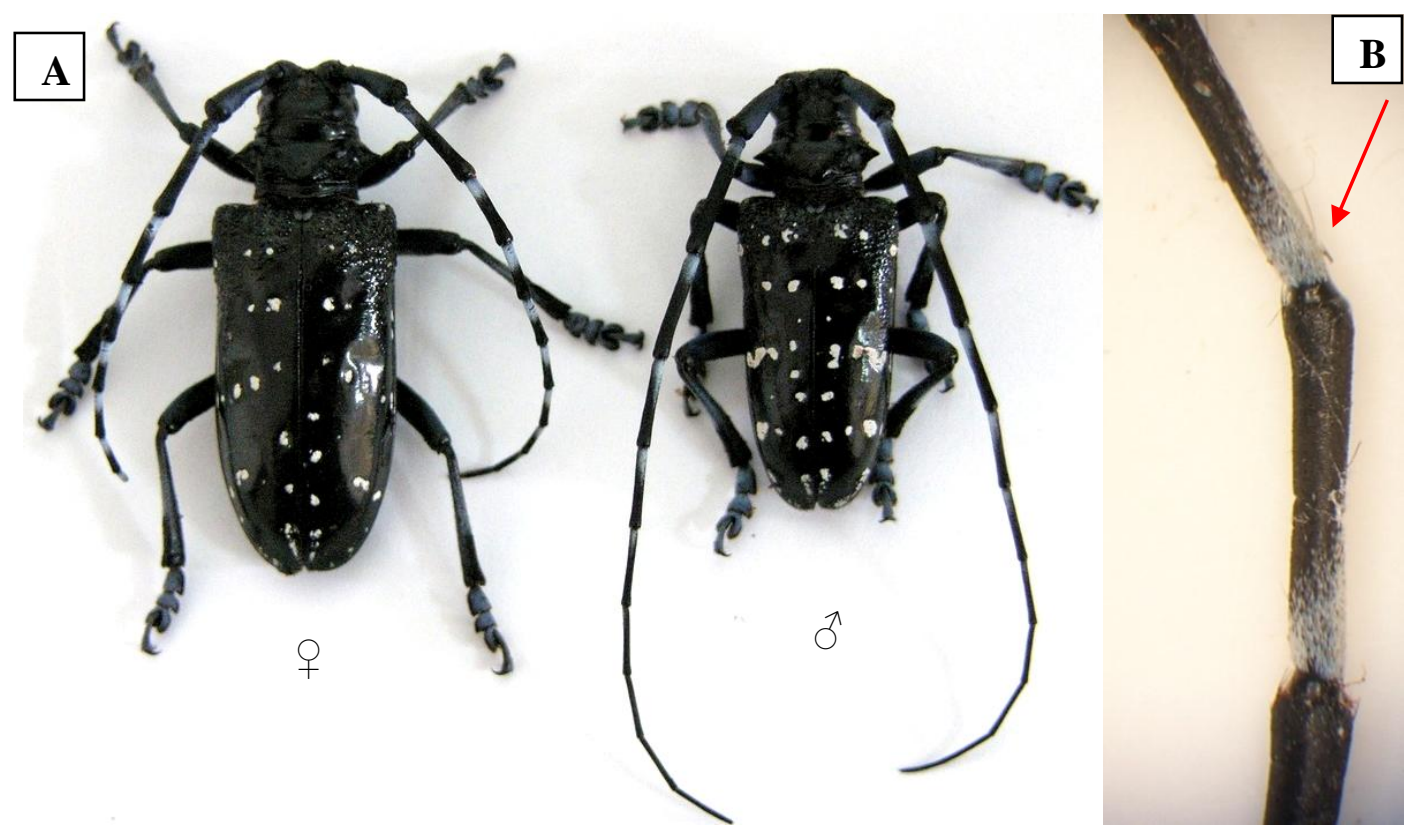




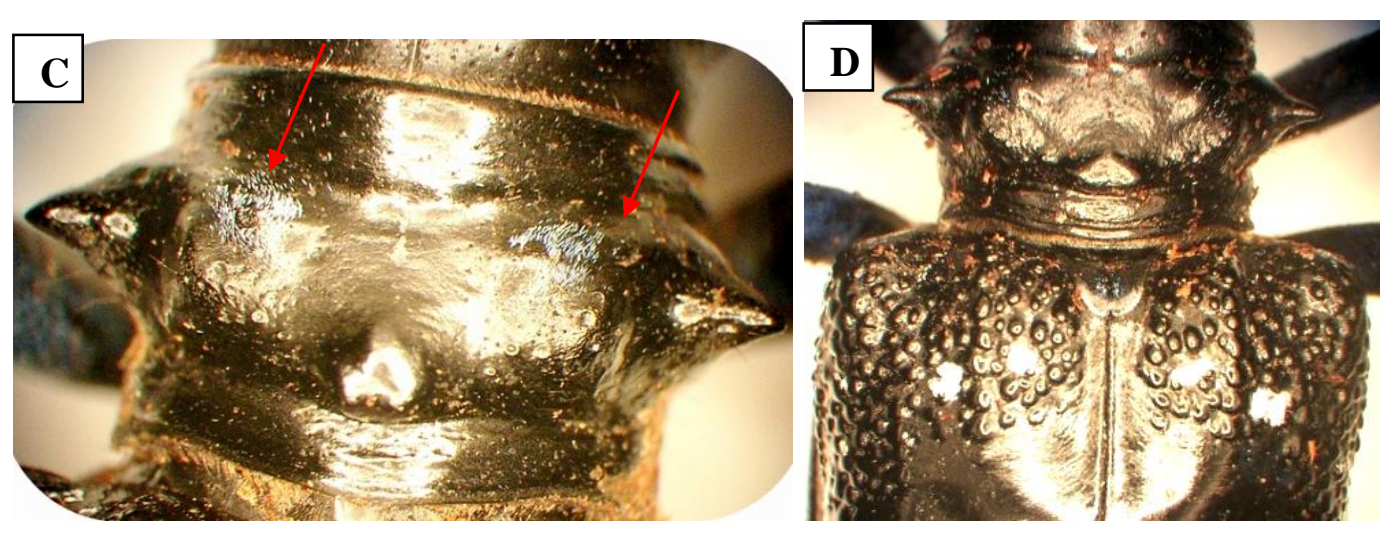

Figure 1. A. Adult of Anoplophora chinensis B. Antenna with blue-white bands C. Pair of stout spines and two blue-white tufts of hair on pronotum D. Tubercules/granulae on the base of the elytra

Distribution: The species has been reported China, Croatia, Germany, Guernsey, Hong Kong, Indonesia, Italy, Japan, Korea, Lithuania, Malaysia, Myanmar, Philippines, Switzerland, Taiwan and Vietnam (EPPO, 2014).

Host plants: Acer spp., Aesculus hippocastanum, Alnus spp., Betula spp., Carpinus spp., Citrus spp., Cornus spp., Corylus spp., Cotoneaster spp., Crataegus spp., Fagus spp., Lagerstroemia spp., Malus spp., Platanus spp., Populus spp., Prunus laurocerasus, Pyrus spp., Rosa spp., Salix spp., Ulmus spp., Casuarina spp., Cryptomeria spp., Ficus spp., Hibiscus spp., Litchi spp., Mallotus spp., Melia spp., Morus spp. and other woody plants (EPPO, 2013b).

In the study, adults of A.chinensis were detected in private nursery on maple trees (Acer palmatum purperea, A. negundo flamingo and A. platanoides) that imported from China. These beetles were recorded in the same time as it was recorded first time in Istanbul by Hizal et al. (2015). Due to its polyphagous character, host plant is considered under high risk of attack, especially Acer species. The pest is a serious problem for the nursery industry, in the production of ornamental trees; it is also a potentially pest of citrus orchards and of many other deciduous trees. Adults feed on the fresh bark of small twigs and branches, and sometimes on leaf petioles. The females also chew from the bark of the host tree to the cambial layer, forming 'egg scars'; then inserts her ovipositor and lays a single egg (Lingafelter and Hoebeke, 2002). Larvae feed and develop in the wood of the main roots and trunks, where they create tunnels. Exit holes have been found only at the base of trees (Figure $2 A-D$ ). Heavy infestations can kill the host trees (Maspero et al., 2005).

This species, is placed at the list of 'Unknown presence and harmful organism for importing' as a part of Agricultural Quarantine Regulations Bylaw -1 An Obstacle Harmful Organism for Importing which is prepared in terms of the law no. 5996 Veterinary Services, Plant Health, Food and Feed promulgated on 13 June 2010 on Official Gazette. In addition, as regard to European Union Anoplophora chinensis commission decision of 1 March 2012 and law no. 2012/138/EC, specifically, by law is prepared and on 17 June 2014 law no. 29033 promulgated on Official Gazette and entered in force (Anonymous, 2014). 

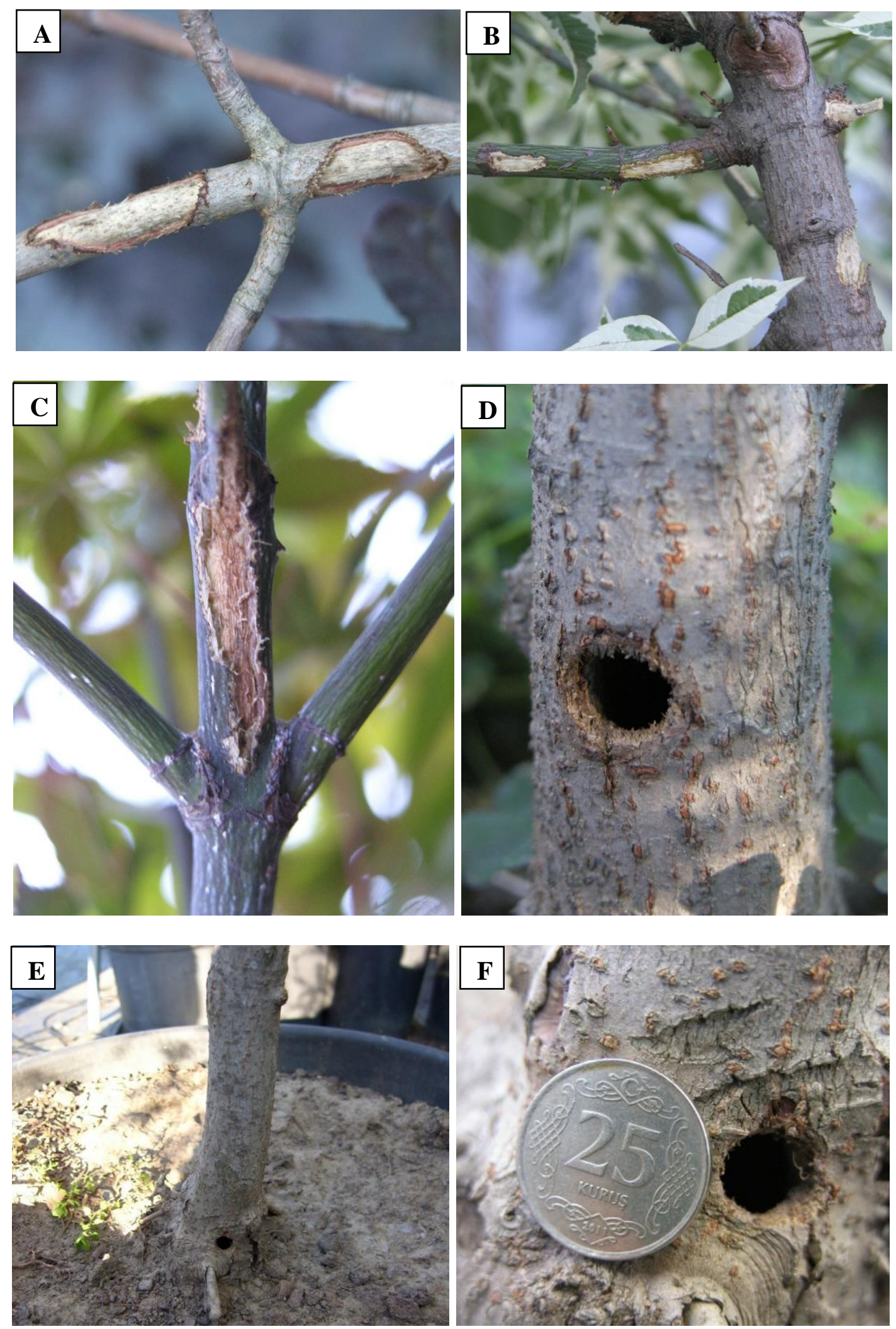

Figure. 2 A-C. Feeding damage of adults D-F. Exit holes 
Most of the known host plants of the citrus longhorned beetle exist also in Turkey. With respect to this, discovering of the releated invasive pest and exploring its new distribution areas in Turkey has a very important value for management of Turkish forests. Ayberk et al. (2014) has reported another invasive longhorned beetle, the Asian longhorned beetle, for the first time in Turkey. The authors has reported the adults of Anoplophora glabripennis were collected from Istanbul province (Zeytinburnu) damaging on Acer negundo trees in July, 2014. For this purpose, as the first step should be to determine real status of invasive Anoplophora species in Turkey. And then to eliminate these extremely dangerous quarantina pests is to remove infested trees and destroy them by chipping or burning immediately. To stop the spread of the citrus and Asian longhorned beetles, it should be to follow the quarantine procedures strictly in infested areas.

\section{REFERENCES}

[1] Anonymous (2014): Ani meşe ölümü ve çam çıralı kanser hastalığı ile Turunçgil uzun antenli böceği ve kestane gal arısı mücadelesi hakkında yönetmelik, sayı: 29033, 17 Haziran 2014 (in Turkish).

[2] Ayberk, H., Ozdikmen, H., Cebeci, H. (2014): A serious pest alert for Turkey: A newly introduced invasive longhorned beetle Anoplophora glabripennis (Cerambycidae: Lamiinae). - Florida Entomologist 97(4): 1852-1855.

[3] Chambers, B. (2002): Citrus longhorned beetle program, King County, Washington: Environmental Assessment. - U.S. Department of Agriculture, Marketing and Regulatory Programs, Animal and Plant Health Inspection Service, $13 \mathrm{pp}$.

[4] EPPO (2013a). Anoplophora chinensis. EPPO data sheet on quarantine pests, Paris, France. 7 pp.

[5] EPPO (2013b). Anoplophora chinensis: procedures for official control. -OEPP/EPPO Bulletin 43(3): 518-526.

[6] EPPO (2014). Database on quarantine pests, PQR database (version 5.3.1). http://www.eppo.int/ DATABASES/pqr/pqr.htm (last accessed 15.06.2014).

[7] FAO (2009). Global review forest pests and diseases. - FAO Forestry Paper 156, Rome, Italy. $24 \mathrm{pp}$.

[8] Gyeltshen, J., Hodges, A. (2005): Citrus Longhorned Beetle, Anoplophora chinensis (Forster) (Insecta: Coleoptera: Cerambycidae). - University of Florida \& IFAS Florida: 14.

[9] Hızal, E., Arslangündoğdu, Z., Göç, A., Ak, M. (2015): The new record for Turkish invasive alien insect fauna Anoplophora chinensis (Forster, 1771) (Coleoptera: Cerambycidae). - Journal of the Faculty of Forestry Istanbul University (JFFIU) 65(1): 711.

[10] Jucker, C., Lupi, D. (2011): Exotic Insects in Italy: An Overview on Their Environmental Impact. - In: Pujol, J.L. (ed.)The Importance of Biological Interactions in the Study of Biodiversity. InTech, China. 51-74 pp.

[11] Lance, D.R. (2002): Anoplophora chinensis introduction in Tukwila, Washington. - In Proceedings of 2002 U.S. Department of Agriculture Interagency Research Forum GTRNE-300.

[12] Lingafelter, S.W., Hoebeke, E.R. (2002): Revision of the Genus Anoplophora (Coleoptera: Cerambycidae). - Entomological Society of Washington, Washington, DC. $236 \mathrm{pp}$.

[13] Maspero, M., Jucker, M., Colombo, C., Ciampitti, M., Cavagna, M., Caremi, B. (2005): The Longhorn Beetle Anoplophora chinensis (form malasiaca), a New Pest of Woody 
Ornamentals in Italy, Plant protection and plant health in Europe: introduction and spread of invasive species. - Humboldt University, Berlin, Germany. 255-256 pp.

[14] Peverieri, G.S., Bertini, G., Furlan, P., Cortini, G., Roversi, P.F. (2012): Anoplophora chinensis (Forster) (Coleoptera Cerambycidae) in the outbreak site in Rome (Italy): Experiences in dating exit holes. - Redia 95: 89-92. 